\section{Immune recovery after antiretroviral therapy initiation: a challenge for people living with HIV in Brazil}

\author{
Recuperação imunológica após o início da terapia \\ antirretroviral: um desafio para pessoas vivendo \\ com HIV no Brasil
}

\section{Recuperación inmunológica tras el inicio de una terapia antirretroviral: un desafío para la gente que vive con VIH en Brasil}

\author{
Cássia C. P. Mendicino 1 \\ Erica E. M. Moodie 2 \\ Mark Drew Crosland Guimarães 3 \\ Cristiane A. Menezes de Pádua 1
}

\begin{abstract}
Immune recovery reflects health conditions. Our goal was to estimate the time it takes to achieve immune recovery and its associated factors, in people living with HIV (PLHIV), after antiretroviral therapy (ART) initiation. A historical cohort study was performed among PLHIV (> 18 years-old) in Minas Gerais State, Brazil, using data from healthcare databases. Patients initiating ART between 2009-2018, with T-CD4+ lymphocytes and viral load recorded before and after antiretroviral therapy were included. The outcome is achievement of immune recovery, defined as the first T-CD $4+>500 \mathrm{cells} / \mu \mathrm{L}$ after ART initiation. Explanatory variables were age, gender, place of residence, year of ART initiation, baseline viral load and T-CD4+, viral load status, and adherence to ART at follow-up. Descriptive analysis, cumulative, and person-time incidences of immune recovery were estimated. Mediantime to immune recovery was estimated using Kaplan-Meier method. Factors associated with immune recovery were assessed by Cox regression. Among 26,430 PLHIV, 8,014 (30\%) were eligible. Most were male (67\%), mean age 38.7 years, resided in non-central region, median-baseline $T$-CD $4+=228$ cells $/ \mu L(<200$ cells $/ \mu L=43 \%)$ and viral load median-baseline $=4.7 \log _{10}$ copies $/ \mathrm{mL}$ (detectable viral load $=99 \%)$. Follow-up time $=15,872$ personyears. Cumulative and incidence rate were 58\% (95\%CI: $57-58)(n=4,678)$ and 29.47 cases/100 person-years, respectively. Median-time to immune recovery was of 22.8 months (95\%CI: 21.9-24.0). Women living with HIV, younger than 38 years of age, with T-CD $4+$ baseline $>200$ cells $/ \mu \mathrm{L}$, detectable viral load (baseline), antiretroviral therapy-adherence and undetectable viral load (follow-up) were independently associated with immune recovery. Time to immune recovery remains long and depends on early treatment and antiretroviral therapy-adherence.
\end{abstract}

\section{Correspondence}

C. C. P. Mendicino

Faculdade de Farmácia, Universidade Federal de Minas Gerais. Av. Antônio Carlos 6627, Belo Horizonte, MG 31270-901, Brasil.

cassiamendicino@gmail.com

1 Faculdade de Farmácia, Universidade Federal de Minas Gerais, Belo Horizonte, Brasil.

2 McGill University, Montreal, Canada.

3 Faculdade de Medicina, Universidade Federal de Minas Gerais, Belo Horizonte, Brasil. 


\section{Introduction}

Antiretroviral therapy (ART) has been shown to be effective in reducing HIV viral load and achieving immune recovery (optimal T-CD4+ lymphocytes count) 1,2. Viral load suppression and immune recovery are the first goals when initiating treatment. Viral load suppression is identified by RNA plasma level and defined according to the detection limit of commercially available testing 2 . In contrast, the interval of normal levels of T-CD4+ ranges widely from 500 to 1,500 cells $/ \mu \mathrm{L}^{3}$. Thus, there is no consensus on how to best identify immune recovery. Some studies focus on a specific T-CD4+ threshold based on guidelines for ART initiation (e.g. 200, 350 or 500 cells $/ \mu \mathrm{L}$ ), whereas others focus on the rate of increase of T-CD4+ over time (i.e., the T-CD4+ slope) 4.

After ART initiation, the time needed to achieve viral load suppression is typically measured in months, while immune recovery may take years. The median time for viral load suppression ranges from 3.4 months to 4.5 months regardless of the ART regime 5,6. In contrast, immune recovery is a gradual process which takes place over a long period of time. The initial reconstitution of T-CD4+ occurs up to 6 months, from the beginning of treatment. In a second phase, the increase in T-CD4+ counts is slower and lasts up to 2 years following treatment initiation. Finally, the last and slowest phase of recovery can last 7 years or more 2 .

Multifactorial determinants may delay, or prevent, immune recovery even after effective response to ART; and the mechanisms that lead to discordant immune response are not well understood 4,7. Older age, persistent immune activation, low level of continuous HIV replication, coinfections, and low pre-therapeutic and lower T-CD4+ counts after ART initiation may predispose individuals to have poor immune recovery 7,8,9. Additionally, some studies have shown that antiretroviral agents - such as zidovudine - may be toxic for hematopoietic progenitor cells 2, further delaying immune recovery. Other studies have reported a better immunological response with the use of integrase inhibitor 10.

Immune recovery is an indicator of improvement in the health in those who seek treatment. An impaired immunological response is linked to increased risk of disease progression and even death; managing immune failure is complex 2,11. People living with HIV (PLHIV) who experience immune recovery through ART have mortality rates close to HIV-negative individuals of same age and gender 12. A study of 80,642 HIV patients from 31 European countries who initiated ART between 1998 and 2008 found a similar mortality rate in heterosexuals with HIV, who maintained T-CD4+ counts $>500$ cells $/ \mu$ L over 5 years 12 . A systematic review showed that the risk of mortality varied from $1 \%$ to $7 \%$ (median follow-up 3.7 years) for patients who attained immune recovery, and from $3 \%$ to $23 \%$ (median follow-up 2 years) for those who failed to attain immune recovery 7.

Recently, notable improvements in antiretroviral therapy's ability to suppress the viral load has resulted in an increase of PLHIV who are undergoing treatment, consequently reducing the transmission of HIV 5. There has been a growing interest in understanding the prognosis of those who undergo ART, and the risks of undesirable long-term outcomes. Immune recovery is a critical component to understanding the health status and predicting the occurrence of chronic disorders in PLHIV. The aim of this study is to estimate the time it takes to achieve immune recovery, and investigate potential contributing factors, in a cohort of PLHIV, who have initiated ART from 2009 through to 2018, in Minas Gerais State, Brazil.

\section{Methods}

\section{Study design and population}

A historical cohort study was carried out within an open cohort of PLHIV who began ART between January 1, 2009, and December 31, 2018, in Minas Gerais State. HIV infected individuals aged 18 years or older, with baseline T-CD4+ $\leq 500$ cells $/ \mu \mathrm{L}$, and with documented viral load and T-CD4+ counts (before and after ART initiation) were eligible for analysis. The study was approved by the Ethics Research Committee of the Federal University of Minas Gerais (CAAE 627.10316.8.0000.5149). 


\section{Data source and outcome}

Laboratory data (viral load and T-CD4+ measurements), therapeutic variables (ART use and adherence), and demographic variables (age, gender, and place of residence) were obtained from two national healthcare databases of the Brazilian Unified National Health System (SUS): Medication Logistics Control System (SICLOM) and Laboratory Test Control System (SISCEL), required nationwide for ART dispensing and laboratory results, respectively ${ }^{13}$. Both, SICLOM and SISCEL, had the same identification number for each patient, which allowed the linkage of the databases.

ART is provided free of charge to all PLHIV in Brazil, through public healthcare facilities. Thus, ART dispensing data covers PLHIV accessing public and private health care. SISCEL covers mainly (but not exclusively) PLHIV from public health care 13 .

Our outcome of interest was the attainment of immune recovery, defined by the first T-CD4+ count $>500$ cells $/ \mu \mathrm{L}$ (the first limit of T-CD4+ normal level) observed during follow-up 14, among those with initial T-CD4+ count $<500$ cells $/ \mu \mathrm{L}$. Follow-up time was defined as the period between the date of the first ART prescription and the date of the first occurrence of T-CD4+ counts $>500$ cells $/ \mu \mathrm{L}$ (outcome) or the last date at which T-CD4+ counts $<500$ cells/ $\mu \mathrm{L}$ was recorded (censoring). The date of ART initiation was based on the first date of treatment dispensing, after checking that there was no other record of ART in the previous three years.

\section{Baseline variables}

Baseline variables, collected at ART initiation date were age, gender, place of residence (central or non-central region within Minas Gerais State), year of ART initiation (before or after 2013), viral load measurements, and T-CD4+ counts. Viral load measurements ( $\log _{10}$ scale) and T-CD4+ counts were obtained within 3 months prior to ART initiation. The central region, where the state capital is located, comprised approximately $28 \%$ of the state population $(5,384,904$ inhabitants), while the population of the non-central region was estimated at 15,783,887 inhabitants, in 201915 . The year 2013 was chosen as the threshold for ART initiation due to the change in national HIV recommendation guidelines to early treatment initiation concerning the T-CD4+ counts or clinical stage 16,17.

\section{Data management and time-varying variables}

Viral load status and ART adherence were time-varying variables evaluated during the follow-up period. Each T-CD4+ segment - period between two consecutive dates of T-CD4+ count of the same individual in the follow-up period - is associated with a time-updated viral load status and ART adherence assessed within the segment.

Viral load status was classified as undetectable $\left(<1.69 \log _{10}\right.$ copies $\left./ \mathrm{mL}\right)$, detectable $\left(>1.69 \log _{10}\right.$ copies $/ \mathrm{mL}$ ), or absent (no measurement) 18. When there was more than one viral load result within the same T-CD4+ segment, the last measurement was considered. The mean time of ART dispensing within each T-CD4+ segment was used as proxy for treatment adherence 19 . It was calculated by dividing the duration, in days, of each T-CD4+ segment by the number of registered ART prescriptions dispensed within the corresponding segment. Intervals $<45$ days were classified as ART adherence and intervals $>45$ days were classified as absence of ART adherence. If no ART was dispensed within the T-CD4+ segment, the individual was considered adherent if the final date of the segment fell within 45 days of the last ART dispensing.

\section{Data analysis}

Descriptive analysis was performed to characterize the study's population. Absolute and relative frequencies, mean, standard deviation (SD), median, and inter-quartile range (IQR) were calculated. Cumulative and person-time incidences of immune recovery were estimated. Cumulative incidence of immune recovery was calculated by dividing the number of individuals who achieved immune recovery by the total of individuals at baseline. Person-time incidence of immune recovery was calculated dividing the number of individuals who achieved immune recovery by the total person-time 
of all individuals during the follow-up, corresponding to the period between the data of the first ART prescription and the date of the immune recovery occurrence (outcome) or the last date of T-CD4+ counts $<500$ cells $/ \mu \mathrm{L}$ (censoring).

Overall median time to immune recovery and time to immune recovery stratified by baseline variables were estimated by the Kaplan-Meier method with 95\% confidence intervals (95\%CI). For time-varying variables (ART adherence and viral load status), stratified Kaplan-Meier curves were calculated based on the information recorded in the first T-CD4+ segment of follow-up 20.

The association between potential explanatory variables and immune recovery attainment was assessed by Cox proportional hazard regression models 21 . Univariate analyses were conducted, followed by multivariate modeling. The final model was selected by the likelihood ratio test 21 . The magnitude of the associations was estimated using adjusted hazard ratio (HR), with 95\%CI. The assumption of proportionality of the hazard was assessed by Schoenfeld residual analysis 21. Database management and statistical analyses were performed using the Statistical Analysis System (SAS), version 9.4 (https://www.sas.com/), and R Software, version 3.0.1 (http://www.r-project.org), respectively.

\section{Results}

\section{Study population description}

Among 26,430 HIV individuals who initiated ART - with at least one T-CD4+ and viral load data recorded between January 1, 2009, and December 31, 2018, in Minas Gerais State -, 8,014 (30\%) met the criteria for inclusion in the cohort (Figure 1). The main reasons for the exclusions were lack of T-CD4+ counts and viral load results before (45.7\%) and after (28.9\%) ART initiation. Approximately $20 \%(\mathrm{n}=3,067)$ of the individuals had T-CD4+ counts $>500 \mathrm{cells} / \mu \mathrm{L}$ at baseline and were not included in this analysis (prevalent cases) (Figure 1). Among the main characteristics of the prevalent cases is the mean (SD) of baseline T-CD4+ of 674 (134) cells $/ \mu \mathrm{L}$.

Baseline characteristics are presented in Table 1. Approximately $50 \%$ of the study population initiated ART before 2013, 67\% ( $\mathrm{n}=5,365)$ were male, had mean (SD) age of 38.7 (11.5) years old, and 4,270 (53\%) lived in non-central region. The median (IQR) and the mean (SD) baseline T-CD4+ was 237 (108-334) cells $/ \mu \mathrm{L}$ and 228 (137) cells $/ \mu \mathrm{L}$, respectively, and $43 \%$ had T-CD4+ counts $<200$ cells $/ \mu \mathrm{L}$. The median (IQR) viral load was $4.7(4.2-5.3) \log _{10}$ copies $/ \mathrm{mL}$ and approximately $99 \%$ of the individuals presented detectable viral load $\left(>1.69 \log _{10}\right.$ copies $\left./ \mathrm{mL}\right)$.

\section{Follow-up and median time to immune recovery}

The median (IQR) duration of follow-up was 14.0 (5.4-32.2) months while the total follow-up time was 15,874 person-years. The median (IQR) number of T-CD4+ segments within the follow-up was 2 (1-5). The cumulative incidence of immune recovery was $58 \%(95 \%$ CI: $57-58)(n=4,678)$, corresponding to an incidence rate of $29.47 / 100$ person-years. The median time to immune recovery was estimated at 22.8 months (95\%CI: 21.9-24.0). Those who presented a shorter median time to immune recovery were female, less than 38 years of age, living in central region; they had initiated ART after 2013, baseline T-CD4+ count $>350$ cells $/ \mu \mathrm{L}$, detectable viral load at baseline, and undetectable viral load and ART adherence during follow-up (Table 2).

Baseline T-CD4+ counts and ART therapy adherence measured at follow-up showed a considerable effect on the median time to immune recovery. Participants with T-CD4+ counts $>350$ cells $/ \mu \mathrm{L}$ at ART initiation achieved immune recovery, approximately, 10.5 times faster than individuals with T-CD4+ counts $<200$ cells $/ \mu \mathrm{L}$ : median time $=5.8$ months and 60.7 months, respectively (Table 2 ; Figure 2). Similarly, ART adherence during follow-up decreased the median time to immune recovery more than 7-fold: median time $=7.7$ months compared to 57.6 months in ART no adherence (Table 2; Figure 2). Slight differences in the Kaplan-Meier curves were found for gender, age, place of residence and year of ART initiation. 


\section{Figure 1}

Study flow of people living with HIV (PLHIV) initiating antiretroviral therapy (ART) between 2009 and 2018. Minas Gerais State, Brazil.

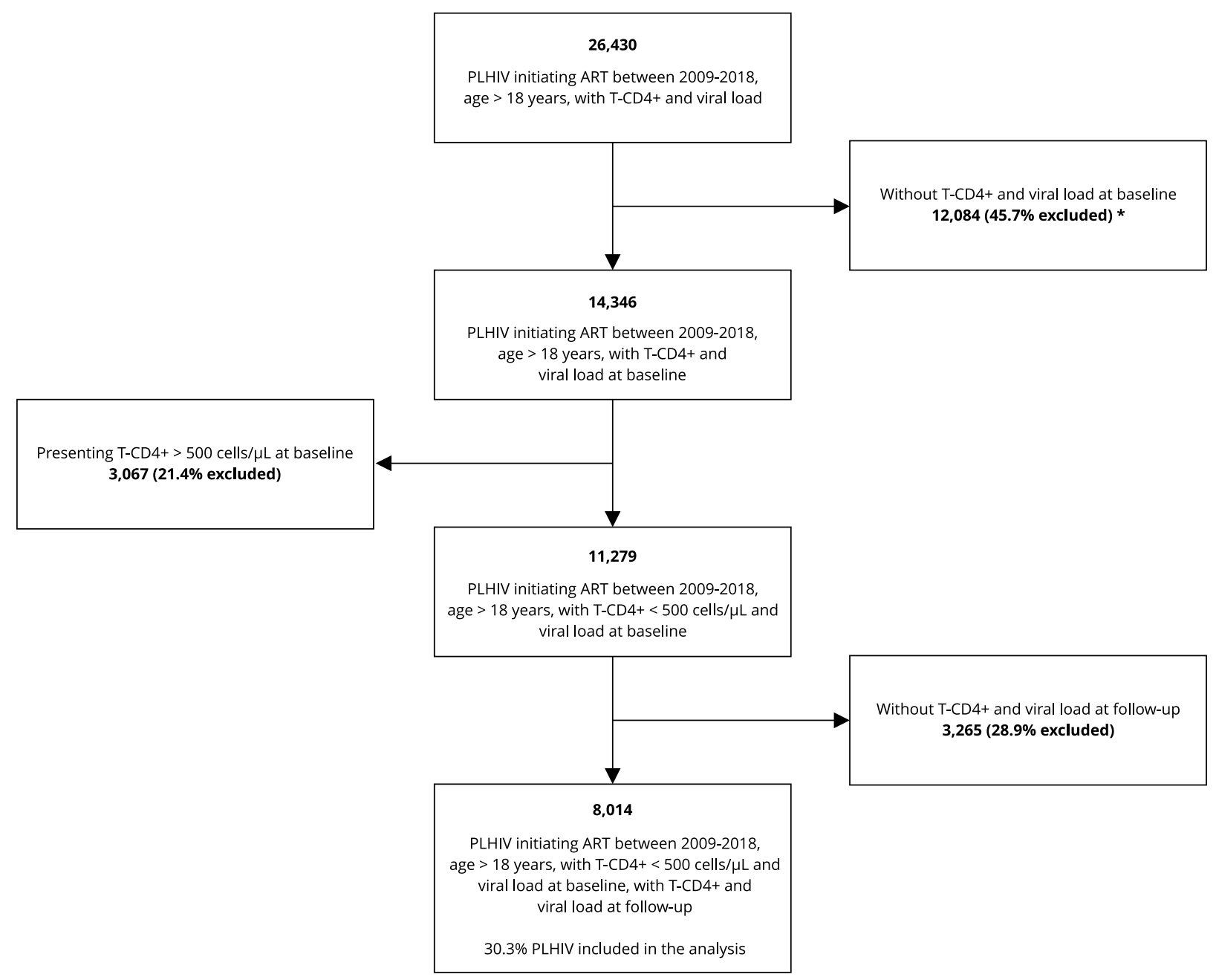

* Until 3 months prior to the start of study.

\section{Univariate and multivariate Cox regression analyses}

All covariables were statistically significant $(\mathrm{p}<0.05)$ predictive of time to immune recovery in the univariate analysis and were therefore included in the multivariate modeling. To obtain a parsimonious model, period of ART initiation and place of residence were removed from the final model. Thus, age, gender, baseline T-CD4+ counts, baseline viral load, ART adherence, and viral load at follow-up remained in the final multivariate model (Table 3). Women, 38 years-old and younger, were less associated with immune recovery: $\mathrm{HR}=1.12$ (95\%CI: $1.06-1.19)$ and $\mathrm{HR}=1.22$ (95\%CI: $1.15-1.30$ ), according to the univariate analysis and multivariate modeling, respectively. Additionally, baseline T-CD $4+$ counts of $>350$ cells $/ \mu \mathrm{L}(\mathrm{HR}=7.36$; 95\%CI: 6.79-7.98), detectable viral load at baseline $(\mathrm{HR}=$ 1.77; 95\%CI: 1.36-2.31), presence of ART adherence at follow-up (HR = 3.09; 95\%CI: 2.84-3.36), and undetectable viral load at follow-up $(\mathrm{HR}=1.45$; 95\%CI: $1.33-1.59)$ showed stronger associations with immune recovery (Table 3). The final model explained $77 \%$ of the variability in outcomes, Schoenfeld residual analysis indicated adequate proportionality of risks for gender and viral load baseline. 
Table 1

Descriptive analysis of baseline variables of people living with HIV who initiated antiretroviral therapy (ART) between 2009 and 2018. Minas Gerais State, Brazil.

\begin{tabular}{|c|c|}
\hline Characteristics/Categories or statistics & $\begin{array}{l}\text { Study population } \\
\qquad(\mathrm{N}=8,014)\end{array}$ \\
\hline \multicolumn{2}{|l|}{ Year ART initiation [n (\%)] } \\
\hline Before 2013 & $4,020(50)$ \\
\hline After 2013 & $3,994(50)$ \\
\hline \multicolumn{2}{|l|}{ Gender $[n(\%)]$} \\
\hline Male & $5,365(67)$ \\
\hline Female & $2,649(33)$ \\
\hline \multicolumn{2}{|l|}{ Age (years) } \\
\hline Median (IQR) & $37.3(29.7-46.2)$ \\
\hline Mean (SD) & $38.7(11.5)$ \\
\hline \multicolumn{2}{|l|}{ Place of residence [n (\%)] } \\
\hline Central & $3,744(47)$ \\
\hline Non-central & $4,270(53)$ \\
\hline \multicolumn{2}{|l|}{ Baseline T-CD4+ lymphocytes (cells/ $\mu \mathrm{L}$ ) } \\
\hline Median (IQR) & $237(108-334)$ \\
\hline Mean (SD) & $228(137)$ \\
\hline \multicolumn{2}{|c|}{ Baseline T-CD4+ lymphocytes distribution (cells/ $\mu \mathrm{L}$ ) [n (\%)] } \\
\hline$<200$ & $3,443(43)$ \\
\hline 200-349 & $2,899(36)$ \\
\hline $350-500$ & $1,672(21)$ \\
\hline \multicolumn{2}{|l|}{ Baseline viral load ( $\log _{10}$ copies $/ \mathrm{mL}$ ) } \\
\hline Median (IQR) & $4.7(4.2-5.3)$ \\
\hline Mean (SD) & $4.7(0.9)$ \\
\hline \multicolumn{2}{|l|}{ Baseline viral load distribution [n (\%)] } \\
\hline Undetectable * & $107(1)$ \\
\hline Detectable ** & 7,907 (99) \\
\hline
\end{tabular}

IQR: inter-quartile range; SD: standard deviation.

$*<1.69 \log _{10}$ copies $/ \mathrm{mL}$;

** $>1.69 \log _{10}$ copies $/ \mathrm{mL}$.

\section{Discussion}

Our study estimated the median time needed for immune recovery for PLHIV, from a large Brazilian state, undergoing ART, and assessed the potential factors, such as: age, gender, year of ART initiation, place of residence, T-CD4+ counts, viral load measurements and treatment adherence.

During the study period, Brazilian HIV guidelines were updated concerning the optimal threshold of baseline T-CD4+ to initiate ART. Since 2013, the T-CD4+ threshold increased from 350 to 500 cells $/ \mu \mathrm{L}$ and, after 2017, the recommendation was to make ART available to all PLHIV, regardless of T-CD4+ counts 17,22. Despite these dynamic updates, our study indicated that a considerable proportion of individuals had late ART initiation over the study period: $56 \%$ and $44 \%$ of the participants initiated treatment with T-CD4+ counts less than 200 cells/ $\mu \mathrm{L}$ before and after 2013, respectively. Similar results were observed in a large study in South Africa. In 844,699 HIV individuals initiating ART between January 2010, and December 2014, the study estimated the proportion of baseline T-CD $4+<200$ cells $/ \mu \mathrm{L}$ varying from $58 \%$ to $36 \% 23$.

A high proportion (42\%) of individuals did not achieve immune recovery in our study, despite the long period of follow-up. Our findings are similar to a study in the South Africa, in which 55.6\% ( $n=469,825$ ) of HIV participants did not achieve immune recovery and the median time (IQR) to immune recovery was estimated to be $17.3(10.0-29.6)$ months 23 . Since there is a higher risk of AIDS, 
Table 2

Median time to immune recovery in people living with HIV initiating antiretroviral therapy (ART) between 2009 and 2018. Minas Gerais State, Brazil.

\begin{tabular}{|c|c|c|c|c|}
\hline Characteristics/Categories & $\mathbf{n}$ & Event (\%) & $\begin{array}{c}\text { Median-time } \\
\text { (months) }\end{array}$ & $95 \% \mathrm{Cl}$ \\
\hline Overall & 8,014 & $4,678(58)$ & 22.8 & $21.9-24.0$ \\
\hline \multicolumn{5}{|l|}{ Period of ART initiation } \\
\hline Before 2013 & 4,020 & $2,800(70)$ & 24.6 & $22.9-26.2$ \\
\hline After 2013 & 3,994 & $1,878(47)$ & 21.8 & $19.8-23.3$ \\
\hline \multicolumn{5}{|l|}{ Gender } \\
\hline Male & 5,365 & $2,975(55)$ & 24.2 & $22.8-25.9$ \\
\hline Female & 2,649 & $1,703(64)$ & 20.9 & 19.3-22.4 \\
\hline \multicolumn{5}{|l|}{ Age (years) } \\
\hline$>38$ & 3,805 & $2,108(55)$ & 27.7 & 26.2-29.6 \\
\hline$<38$ & 4,209 & $2,570(61)$ & 19.2 & $18.0-20.7$ \\
\hline \multicolumn{5}{|l|}{ Residence region } \\
\hline Non-central & 4,270 & $2,532(59)$ & 23.7 & 22.1-25.1 \\
\hline Central & 3,744 & $2,146(57)$ & 22.2 & $20.9-23.8$ \\
\hline \multicolumn{5}{|c|}{ BaselineT-CD4+ lymphocytes (cells/ $\mu \mathrm{L}$ ) } \\
\hline$<200$ & 3,443 & $1,200(35)$ & 60.7 & $56.4-66.3$ \\
\hline $200-349$ & 2,899 & $2,057(71)$ & 15.5 & $14.7-16.2$ \\
\hline $350-500$ & 1,672 & $1,421(85)$ & 5.8 & $5.5-6.3$ \\
\hline \multicolumn{5}{|l|}{ Baseline viral load distribution } \\
\hline Undetectable * & 107 & $55(51)$ & 38.2 & $30.8-98.9$ \\
\hline Detectable ** & 7,907 & $4,623(58)$ & 22.6 & $21.8-23.8$ \\
\hline \multicolumn{5}{|l|}{ ART adherence follow-up *** } \\
\hline Absence & 1,058 & $181(17)$ & 57.6 & 55.8-NA \\
\hline Presence & 6,956 & $1,670(24)$ & 7.7 & $7.2-8.3$ \\
\hline \multicolumn{5}{|l|}{ Viral load follow-up $* * *$} \\
\hline Detectable ** & 426 & $113(27)$ & 14.5 & 10.7-29.1 \\
\hline Undetectable * & 185 & $77(42)$ & 13.8 & $12.4-20.2$ \\
\hline No measure & 7,403 & $1,661(22)$ & 11.0 & $11.0-13.7$ \\
\hline
\end{tabular}

95\% Cl: 95\% confidence interval; NA: not available.

* $<1.69 \log _{10}$ copies $/ \mathrm{mL}$;

$\star \star>1.69 \log _{10}$ copies/mL;

$\star \star *$ The median time based on the first T-CD4+ segment of follow-up.

non-AIDS diseases, and even death occurring in individuals with poor immune recovery, they require continued T-CD4+ monitoring in order to ensure effective management of immune failure 24,25 . The U.S. Office of AIDS Research Advisory Council (OARAC) have maintained the recommendation that T-CD4+ counts should be monitored every 3 to 6 months during the first 2 years of ART initiation, and every 12 months after 2 years of treatment 26 . However, several studies have suggested that T-CD4+ monitoring among virologically suppressed individuals may not be necessary, and the reduction in T-CD4+ tests may free up resources to put more people on ART 27. Nevertheless, most of these studies are randomized trials, which include a reduced sample of patients with higher T-CD4+ counts before ART initiation and immune recovery defined by reduced T-CD4+ threshold of 200 cells $/ \mu \mathrm{L}$ $28,29,30,31$, and thus reduced follow-up may not be advisable in real-world populations with a higher proportion of more immune-compromised patients.

Our study showed that the period of ART initiation, place of residence, gender, and undetectable viral load after ART initiation had a lower impact on the time to immune recovery. After 2013, evidence pointed to a decrease of the HIV transmission through early treatment; as a result, the recommendations concerning ART initiation were updated to immediate treatment after HIV diagnosis 
Figure 2

Estimated time to immune recovery (survival curve) in people living with HIV, initiating antiretroviral therapy (ART) between 2009-2018. Minas Gerais State, Brazil.

2a) General curve



2b) Curve stratified by ART adherence

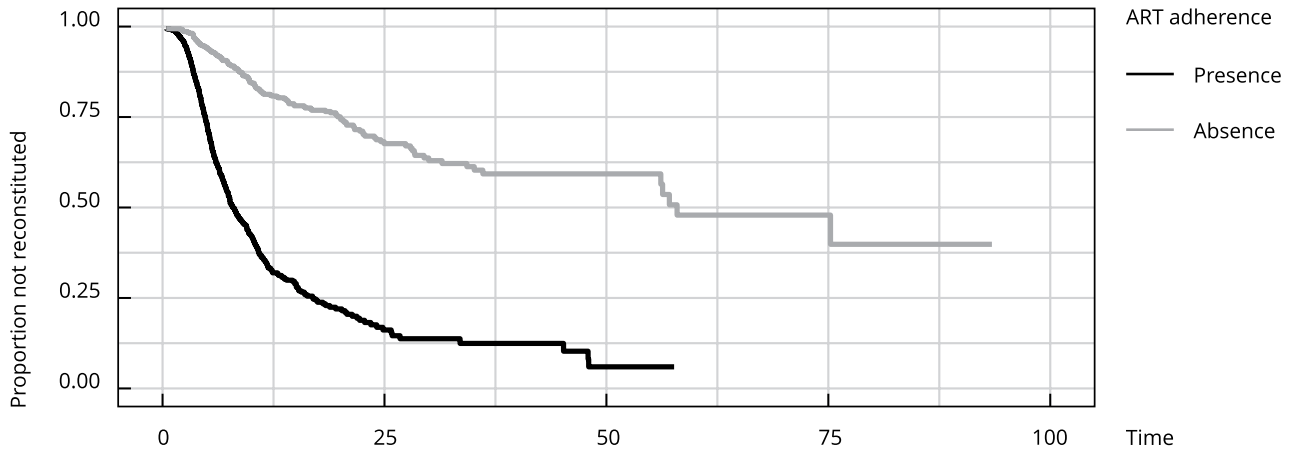

2c) Curve stratified by T-CD4 counts

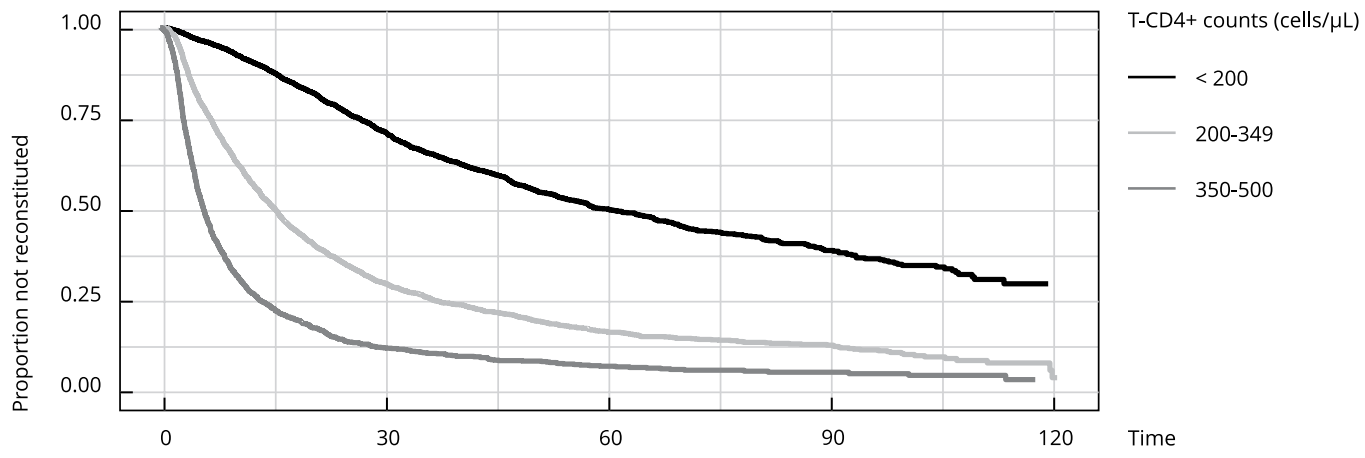


Table 3

Univariate and multivariate Cox regression analyses summarizing the relationship between time to immune recovery and each of baseline and timevarying variables, in people living with HIV initiating antiretroviral therapy (ART) between 2009-2018. Minas Gerais State, Brazil (N = 8,014).

\begin{tabular}{|c|c|c|c|c|c|c|}
\hline \multirow[t]{2}{*}{ Characteristics/Categories } & \multicolumn{3}{|c|}{ Univariate analysis } & \multicolumn{3}{|c|}{ Multivariate analysis } \\
\hline & HR & $95 \% \mathrm{Cl}$ & p-value & HR & $95 \% \mathrm{Cl}$ & p-value \\
\hline \multicolumn{7}{|l|}{ Gender } \\
\hline Male & 1.00 & & & 1.00 & & \\
\hline Female & 1.15 & $1.08-1.22$ & $<0.01$ & 1.12 & $1.06-1.19$ & $<0.01$ \\
\hline \multicolumn{7}{|l|}{ Age (years) } \\
\hline$>38$ & 1.00 & & & 1.00 & & \\
\hline$<38$ & 1.26 & $1.19-1.34$ & $<0.01$ & 1.22 & $1.15-1.30$ & $<0.01$ \\
\hline \multicolumn{7}{|c|}{ Baseline T-CD4+ lymphocytes (cells/ $\mu \mathrm{L}$ ) } \\
\hline$<200$ & 1.00 & & & 1.00 & & \\
\hline $200-349$ & 3.06 & $2.85-3.29$ & $<0.01$ & 3.32 & $3.09-3.58$ & $<0.01$ \\
\hline $350-500$ & 6.35 & $5.87-6.87$ & $<0.01$ & 7.36 & $6.79-7.98$ & $<0.01$ \\
\hline \multicolumn{7}{|c|}{ Baseline viral load (log $\log _{10}$ copies/mL) } \\
\hline Undetectable * & 1.00 & & & 1.00 & & \\
\hline Detectable ** & 1.49 & $1.14-1.94$ & $<0.01$ & 1.77 & $1.36-2.31$ & $<0.01$ \\
\hline \multicolumn{7}{|l|}{ ART adherence follow-up } \\
\hline Absence & 1.00 & & & 1.00 & & \\
\hline Presence & 2.47 & $2.28-2.68$ & $<0.01$ & 3.09 & $2.84-3.36$ & $<0.01$ \\
\hline \multicolumn{7}{|c|}{ Viral load follow-up ( $\log _{10}$ copies/mL) } \\
\hline Detectable ** & 1.00 & & & 1.00 & & \\
\hline Undetectable * & 1.58 & $1.45-1.72$ & $<0.01$ & 1.45 & $1.33-1.59$ & $<0.01$ \\
\hline No measure & 2.19 & $2.01-2.38$ & $<0.01$ & 2.04 & $1.87-2.22$ & $<0.01$ \\
\hline \multicolumn{7}{|l|}{ Period of ART initiation } \\
\hline Before 2013 & 1.00 & & & & & \\
\hline After 2013 & 1.14 & $1.08-1.22$ & $<0.01$ & & & \\
\hline \multicolumn{7}{|l|}{ Place of residence } \\
\hline Non-central & 1.00 & & & & & \\
\hline Central & 1.07 & $1.01-1.13$ & 0.03 & & & \\
\hline
\end{tabular}

95\% Cl: 95\% confidence interval; HR: hazard risk.

* $<1.69 \log _{10}$ copies/mL;

$\star \star>1.69 \log _{10}$ copies/mL.

regardless of T-CD4+ count 17 . However, our results showed that the period of ART initiation had little effect over immune recovery. These findings were likely a consequence of the lower baseline T-CD4+ counts over the years 2009-2018. In fact, the means (SD) of T-CD4+ counts (220 cells $/ \mu \mathrm{L}$ vs. 236 cells $/ \mu \mathrm{L}$ ) and proportions of patients with T-CD $4+$ count $<200$ cells $/ \mu \mathrm{L}$ ( $42 \%$ vs. $43 \%$ ) were similar for both periods (data not shown). Several studies have emphasized the importance of early treatment over immune recovery. Researchers have reported a massive and permanent damage in the structure of lymphatic tissues induced by HIV before ART initiation, that should determine the level of immune reconstitution 32. Further studies are needed to clarify this issue. We noted that there is an uneven distribution of reported AIDS cases and treatment referral centers between central and noncentral regions of the State: out of 2,440 notifications of AIDS cases in Minas Gerais State in 2018, 999 cases (41\%) were reported in the central region, where only $12 \%$ of the public referral centers for HIV/AIDS care are also located 33,34. This could partially explain the borderline effect on the time to immune recovery according to regions. Concerning gender, there are several evidences indicating that time to achieve immune recovery is usually higher among men than women 8,35,36. Although, our findings showed that the median time and HR to immune recovery was barely influenced by gender. 
We found that immune recovery was associated with detectable baseline viral load and undetectable viral load at follow-up. In fact, levels of T-CD4+ at ART initiation and their changes over the course of ART-treated HIV infection (T-CD4+ slope) are the most important predictors of immune recovery achievement 24,25 and viral load measurements may indirectly contribute to successful immune recovery. The literature shows that detectable viral load at ART initiation requires closer viral load monitoring with more frequent measurements, which would improve ART adherence, leading to viral load suppression and immune recovery 5,37,38.

Finally, higher T-CD4+ counts at the ART initiation and treatment adherence at follow-up were the strongest predictors of immune recovery occurrence. Late ART initiation and adherence have remained key challenges in HIV control. In Brazil, since 2016, approximately $26 \%$ of PLHIV have had a late treatment start ${ }^{39}$. Two cross-sectional studies, performed in $2010(\mathrm{~N}=1,970)$ and $2017(\mathrm{~N}=$ 356) in Brazilian Northeast, estimated a proportion of late ART initiation of $50 \%$ and $41 \%$, respectively 40,41 . Some factors associated with late ART initiation comprised lower risk behaviors, probably due to a lack of perception of HIV infection risk: heterosexual couples with children, one sexual partner, no drug users, no history of sexually transmitted infection 40,41,42. These results reinforce the need for HIV testing. Different measurement tools and ART adherence definitions used across different studies may limit comparisons. However, there is a broad consensus that ART adherence remains a challenge for HIV control worldwide 43 . In Brazil, non-adherence estimates ranged from $25 \%$ to 30\% between 2015 and 2018 39. A Brazilian cross-sectional study ( $N=120)$ conducted between 2007 and 2014 showed a prevalence of non-adherence of $43.3 \%$ 44. Missing medical appointments, mental health conditions, adverse effects of ART and use of illicit drugs are some risk factors associated with non-adherence to treatment 43,45,46. On the other hand, the presence of AIDS diagnosis, which requires more frequent T-CD4+ measurements, improves adherence to ART and also, as a result, immune recovery monitoring. Thus, male, older patients, with low T-CD4+ counts and undetectable viral load at ART initiation, presenting non-adherence to ART and detectable viral load during treatment should be prioritized for T-CD4+ monitoring in order to ensure immune recovery.

Some limitations of our study must be addressed. First, the sample was remarkably reduced from the total population of PLHIV due to the unavailability of T-CD4+ and viral load results before and after the start of ART. A large proportion of missing data were probably due to individuals receiving healthcare in Minas Gerais state (27\%), including T-CD4+ counts and viral load monitoring, at private services (Brazilian Health Informatics Department. http://tabnet.datasus.gov.br/cgi/tabcgi. exe?idb2012/f16.def, accessed on 21/Sep/2020), whose data have not to be compulsorily recorded in the SUS databases. Despite the recognized importance of T-CD4+ count in evaluating disease status at baseline, it is possible that some patients, especially those who were clinically stable, had initiated ART without performing T-CD4+ count in view of the recommendations of early treatment initiation since 2013 17. Additionally, the shift to viral load monitoring in ART could explain, partially, rates of missing T-CD4+ count in the follow-up period. Lastly, the increased demand for laboratory monitoring, generated from the early ART initiation, can be a challenge for low- and middle-income countries in providing adequate coverage of both T-CD4+ count and viral load tests. In an African study aimed at predicting T-CD $4+$ count recovery, the number of participants was reduced by $83 \%$ (from $3,981,104$ to $1,070,900$ ) mainly due to the missing data on T-CD4+ lymphocytes exams 8 . National studies of Melchior et al. 47 evaluated the quality of HIV public healthcare in seven Brazilian States between 2000 and 2001 ( $N=$ 92,400 patients: 72\% of all Brazilian HIV-patients); they showed that T-CD4+ counts and viral load measurements were available in the majority of services, and yet approximately $50 \%$ did not perform those exams. Currently, there is no known national information regarding this issue. Thus, monitoring the availability and frequency of T-CD4+ count performance may allow realistic and ongoing assessment of immune recovery over time.

Despite the reduction in sample size, it was possible to conduct a longitudinal analysis from available data of a considerable number of PLHIV, providing valuable information for HIV/AIDS healthcare. Further, selecting participants with lower baseline T-CD4+ counts may have led our results to underestimate the frequency of immune recovery. These participants, including those with late diagnosis/treatment and with co-infections (e.g. tuberculosis, hepatitis B and C), are more likely to test routinely and to achieve immune recovery less frequently 48 . In fact, the mean (SD) of baseline 
T-CD4+ counts of population excluded (prevalent cases) was 674 (134) cells $/ \mu \mathrm{L}$ versus 228 (137) cells $/ \mu \mathrm{L}$ of selected population of the study. The last limitation refers to the PLHIV who initiated ART in the latter years of the study period and therefore had limited follow-up time, with unknown contribution to our results.

This study points to the value of using large, linked public databases for following HIV treatment over time. The SISCEL and SICLOM databases were initially created for the management of laboratory results and dispensing of antiretrovirals, however, they have become a widely used source for research purposes. Joining the data from SISCEL and SICLOM with other databases such as Brazilian Information System for Notificable Diseases (SINAN) or Mortality Information System (SIM) represents an important field of research that could assist in clarifying crucial issues concerning the disorders occurred in PLHIV under long-term antiretroviral therapy but with suboptimal immune recovery. For subsequent studies, these data could also be used to verify the effectiveness of recently adopted antiretrovirals, such as dolutegravir, by assessing viral suppression and achievement of immune recovery.

\section{Conclusion}

Our study highlights the importance of early ART initiation, ART adherence and T-CD4+ counts in the attainment of immune recovery. Nevertheless, there is a significant proportion of PLHIV with late ART initiation, which is not in line with the current guidelines of reducing the frequency of T-CD4 counts tests 49 . Thus, interventions to ensure that people living with HIV will be immunologically monitored, besides earlier HIV diagnosis and treatment, represent the main challenges to achieve immune recovery in this Brazilian State.

\section{Contributors}

C. C. P. Mendicino drafted, performed statistical analysis, interpreted the data and edited the manuscript. E. E. M. Moodie reviewed, performed statistical analysis and interpreted the data. M. D. C. Guimarães reviewed the manuscript and C. A. Menezes de Pádua reviewed the manuscript and lead the study.

\section{Additional informations}

ORCID: Cássia C. P. Mendicino (0000-0002-1627292X); Erica E. M. Moodie (0000-0002-72253977); Mark Drew Crosland Guimarães (00000001-7932-3854); Cristiane A. Menezes de Pádua (0000-0001-7083-3188).

\section{Acknowledgments}

We gratefully acknowledge the Chronic Conditions and Sexual Transmissible Infections Department, Brazilian Ministry of Health, for making this study possible, providing data from SISCEL and SICLOM system. To the Minas Gearis State Research Foundation (FAPEMIG; APQ-00778-17) and Brazilian Graduate Studies Coordinating Board (CAPES; process $8887-364669 / 2019-00)$ for the financial support. 


\section{References}

1. Milanés-Guisado Y, Gutiérrez-Valencia A, Trujillo-Rodríguez M, Espinosa N, Viciana P, López-Cortés LF. Absolute CD4+ T cell count overstate immune recovery assessed by $\mathrm{CD} 4+/$ $\mathrm{CD} 8+$ ratio in HIV-infected patients on treatment. PLoS One 2018; 13:e0205777.

2. Corbeau P, Reynes J. Immune reconstitution under antiretroviral therapy: the new challenge in HIV-1 infection. Blood 2011; 117:5582-90.

3. U.S. Department of Veterans Affairs. CD4 count (or T-cell count). https://www.hiv.va. gov/patient/diagnosis/labs-CD4-count.asp (accessed on 27/Mar/2020).

4. Aldrete S, Jang JH, Easley KA, Okulicz J, Dai $\mathrm{T}$, Chen YN, et al. CD4 rate of increase is preferred to CD4 threshold for predicting outcomes among virologically suppressed HIVinfected adults on antiretroviral therapy. PLoS One 2020; 15:e227124.

5. Cescon AM, Cooper C, Chan K, Palmer AK, Klein MB, Machouf N, et al. Factors associated with virological suppression among HIV-positive individuals on highly active antiretroviral therapy in a multi-site Canadian cohort. HIV Med 2011; 12:352-60.

6. Jacobson K, Ogbuagu O. Integrase inhibitorbased regimens result in more rapid virologic suppression rates among treatment-naïve human immunodeficiency virus-infected patients compared to non-nucleoside and protease inhibitor-based regimens in a real-world clinical setting: a retrospective cohort study. Medicine (Baltimore) 2018; 97:e13016.

7. Kelly C, Gaskell KM, Richardson M, Klein N, Garner P, MacPherson P. Discordant immune response with antiretroviral therapy in HIV-1: a systematic review of clinical outcomes. PLoS One 2016; 11:e0156099.

8. Kufa T, Shubber Z, MacLeod W, Takuva S, Carmona S, Bor J, et al. CD4 count recovery and associated factors among individuals enrolled in the South African antiretroviral therapy programme: an analysis of national laboratory based data. PLoS One 2019; 14:e0217742.

9. Gaardbo JC, Hartling HJ, Gerstoft J, Nielsen $\mathrm{SD}$. Incomplete immune recovery in HIV infection: mechanisms, relevance for clinical care, and possible solutions. Clin Dev Immunol 2012; 2012:670957.
10. Wijting IEA, Wit FWNM, Rokx C, Leytenc MSE, Lowe SH, Brinkman K, et al. Immune reconstitution inflammatory syndrome in HIV infected late presenters starting integrase inhibitor containing antiretroviral therapy. EClinicalMedicine 2019; 17:100210.

11. Tincati C, Merlini E, d'Arminio Monforte A, Marchetti G. Is weak CD4+ gain in the course of suppressive combination antiretroviral therapy for HIV infection a current clinical challenge? A case report and brief review of the literature. BMC Infect Dis 2018; 18:2-7.

12. Lewden C, Bouteloup V, Wit S, Sabin C, Mocroft A, Wasmuth JC, et al. All-cause mortality in treated HIV-infected adults with CD4 $\geq$ $500 / \mathrm{mm} 3$ compared with the general population: evidence from a large European observational cohort collaboration. Int J Epidemiol 2012; 41:433-45.

13. Lucena FFA, Fonseca MGP, Sousa AIA, Coeli CM. O relacionamento de bancos de dados na implementação da vigilância da AIDS. Cad Saúde Colet (Rio J.) 2006; 14:305-12.

14. Departamento de Vigilância, Prevenção e Controle das Infecções Sexualmente Transmissíveis, do HIV/Aids e das Hepatites Virais, Secretaria de Vigilância em Saúde, Ministério da Saúde. Protocolo clínico e diretrizes terapêuticas para manejo da infecção pelo HIV em adultos. http://www.aids.gov. $\mathrm{br} / \mathrm{pt}-\mathrm{br} / \mathrm{pub} / 2013 /$ protocolo-clinico-ediretrizes-terapeuticas-para-manejo-dainfeccao-pelo-hiv-em-adultos (accessed on 27/Mar/2020)

15. Instituto Brasileiro de Geografia e Estatística. Estimativas da população brasileira residente no Brasil e Unidades da Federação. https:// agenciadenoticias.ibge.gov.br/agencia-deta lhe-de-midia.html? view $=$ mediaibge $\&$ catid $=21$ 03\&id=3097 (accessed on 27/Mar/2020).

16. Cohen MS, Chen YQ, McCauley M, Gamble T, Hosseinipour MC, Kumarasamy N, et al. Prevention of HIV-1 infection with early antiretroviral therapy. N Engl J Med 2011; 365:493505.

17. Departamento de DST, Aids e Hepatites Virais, Secretaria de Vigilância em Saúde, Ministério da Saúde. Protocolo clínico e diretrizes terapêuticas para manejo da infecção pelo HIV em adultos. http://www.aids.gov.br/pcdt (accessed on $08 / \mathrm{Jul} / 2014$ ) 
18. Centers for Disease Control and Prevention. Guidance on community viral load: a family of measures, definitions, and method for calculation. https://stacks.cdc.gov/view/cdc/28147 (accessed on 01/Apr/2020).

19. Departamento de DST, Aids e Hepatites Virais, Secretaria de Vigilância em Saúde, Ministério da Saúde. Adesão ao tratamento antirretroviral no Brasil: coletânea de estudos do Projeto Atar. https://www.nescon.medicina.ufmg.br/ biblioteca/imagem/3035.pdf (accessed on 01/ Apr/2020).

20. Snapinn SM, Jiang Qi, Iglewicz B. Illustrating the impact of a time-varying covariate with an extended Kaplan-Meier estimator. Am Stat 2005; 59:301-7.

21. Carvalho MS, Andreozzi VL, Codeço CT, Campos DP, Barbosa MTS, Shimakura SE. Análise de sobrevivência: teoria e aplicações em saúde. 2nd Ed. Rio de Janeiro: Editora Fiocruz; 2011.

22. Departamento de Vigilância, Prevenção e Controle das Infecções Sexualmente Transmissíveis, do HIV/Aids e das Hepatites Virais, Secretaria de Vigilância em Saúde, Ministério da Saúde. Protocolo clínico e diretrizes terapêuticas para manejo da infecção pelo HIV em adultos. http://www.aids.gov.br/pcdt (accessed on 27/Mar/2017).

23. Kufa-Chakezha T, De Gita G, Ballah NJ, Puren A, Takuva S, Carmona S, et al. Determinants of CD4 immune recovery among individuals on antiretroviral therapy in South Africa: a national analysis. http://documents.worldbank. org/curated/en/851301474884707261/ Determinants-of-CD4-immune-recoveryamong-individuals-on-antiretroviral-thera py-in-South-Africa-a-national-analysis (accessed on 27/Mar/2020).

24. Achhra AC, Petoumenos K, Law MG. Relationship between CD4 cell count and serious long-term complications among HIV-positive individuals. Curr Opin HIV AIDS 2014; 9:6371.

25. The INSIGHT START Study Group. Initiation of antiretroviral therapy in early asymptomatic HIV infection. N Engl J Med 2015; 373:795807.
26. U.S. Department of Health \& Human Service. Guidelines for the use of antiretroviral agents in adults and adolescents with HIV. http:// www.aidsinfo.nih.gov/ContentFiles/Adultand AdolescentGL.pdf (accessed on 31/Jan/2020).

27. Ford N, Meintjes G, Pozniak A, Bygrave H, Hill A, Peter T, et al. The future role of CD4 cell count for monitoring antiretroviral therapy. Lancet Infect Dis 2015; 15:241-7.

28. Girard PM, Nelson M, Mohammed P, Hill A, van Delft Y, Moecklinghoff C. Can we stop CD4+ testing in patients with HIV-1 RNA suppression on antiretroviral treatment? AIDS 2013; 27:2759-63.

29. Phillips AN, Youle M, Lampe F, Sabin C, Hill A, Ransom D, et al. CD4 cell count changes in individuals with counts above 500 cells $/ \mathrm{mm}$ and viral loads below 50 copies/mL on antiretroviral therapy. AIDS 2002; 16:1073-5.

30. Whitlock GG, Ahmed N, Benn P, Edwards S, Waters L. Stop routine CD4 monitoring in HIV-infected patients with fully suppressed virus and CD4 > 350 cells/ml. Clin Infect Dis 2013; 57:327-8.

31. Gale HB, Gitterman SR, Hoffman HJ, Gordin FM, Benator DA, Labriola AM, et al. Is frequent CD4 + T-lymphocyte count monitoring necessary for persons with counts $\geq 300$ cells/ $\mu \mathrm{L}$ and HIV-1 suppression? Clin Infect Dis 2013; 56:1340-3.

32. Kolte L. Thymic function in HIV-infection. Dan Med J 2013; 60:B4622.

33. Departamento de Doenças de Condições Crônicas e Infecções Sexualmente Transmissíveis, Secretaria de Vigilância em Saúde, Ministério da Saúde. Boletim Epidemiológico HIV/ AIDS 2019. http://www.aids.gov.br/pt-br/ pub/2019/boletim-epidemiologico-de-hivai ds-2019.

34. Secretaria de Estado de Saúde de Minas Gerais. Boletim Epidemiológico Mineiro. Análise epidemiológica de HIV/Aids: panorama do ano de 2018. http://vigilancia.saude.mg.gov. $\mathrm{br} /$ index.php/doencas-por-infeccoes-sexu almente-transmissiveis-hiv-aids-hepatitesvirais/ (accessed on 31/Jan/2020). 
35. Maman D, Pujades-Rodriguez M, Subtil F, Pinoges L, McGuire M, Ecochard R, et al. Gender differences in immune reconstitution: a multicentric cohort analysis in Sub-Saharan Africa. PLoS One 2012; 7:e31078.

36. Han WM, Apornpong T, Kerr SJ, Hiransuthikul A, Do GT, Ruxrungtham K, et al. CD4/ CD8 ratio normalization rates and low ratio as prognostic marker for non-AIDS defining events among long-term virologically suppressed people living with HIV. AIDS Res Ther 2018; 15:2-9.

37. Lecher S, Ellenberger D, Kim AA, Fonjungo PN, Agolory S, Borget MY, et al. Scale-up of HIV viral load monitoring: seven Sub-Saharan African countries. MMWR Morb Mortal Wkly Rep 2015; 64:1287-90.

38. Chakraborty H, Iyer M, Duffus WA, Samantapudi AV, Albrecht H, Weissman S. Disparities in viral load and CD4 count trends among HIV-infected adults in South Carolina. AIDS Patient Care STDs 2015; 29:26-32.

39. Departamento de Doenças de Condições Crônicas e Infecções Sexualmente Transmissíveis, Secretaria de Vigilância em Saúde, Ministério da Saúde. Relatório de monitoramento clínico do HIV. http://www.aids.gov.br/pt-br/ $\mathrm{pub} / 2019 /$ relatorio-de-monitoramento-clini co-do-hiv-2019 (accessed on 21/Sep/2020).

40. MacCarthy S, Brignol S, Reddy M, Nunn A, Dourado I. Late presentation to HIV/AIDS care in Brazil among men who self-identify as heterosexual. Rev Saúde Pública 2016; 50:54.

41. Ribeiro LCS, Freitas MIF, Tupinambás U, Lana FCF. Late diagnosis of human immunodeficiency virus infection and associated factors. Rev Latinoam Enferm 2020; 28:e3342.

42. Khoury Z, Silva RS, Villela W. Factors associated with a delay in seeking HIV/AIDS treatment in São Paulo, Brazil. AIDS Behav 2015; 19:679-83.
43. Santos MA, Guimarães MDC, Helena ETS, Basso CR, Vale FC, Carvalho VMES, et al. Monitoring self-reported adherence to antiretroviral therapy in public HIV care facilities in Brazil: a national cross-sectional study. Medicine (Baltimore) 2018; 97(1S Suppl 1):S38-45.

44. Velame KT, Silva RS, Cerutti Junior C. Factors related to adherence to antiretroviral treatment in a specialized care facility. Rev Assoc Méd Bras 2020; 66:290-5.

45. Corless IB, Hoyt AJ, Tyer-Viola L, Sefcik E, Kemppainen J, Holzemer WL, et al. 90-90-90-Plus: maintaining adherence to antiretroviral therapies. AIDS Patient Care STDs 2017; 31:227-36.

46. Oliveira LS, Caixeta LM, Martins JLR, Segati KD, Moura RS, Daher MC, et al. Adherence to antiretroviral therapy and correlation with adverse effects and coinfections in people living with HIV/AIDS in the municipality of Goiás State. Rev Soc Bras Med Trop 2018; 51:43644.

47. Melchior R, Nemes MIB, Basso CR, Castanheira ERL, Alves MTSB, Buchalla CM, et al. Evaluation of the organizational structure of HIV/AIDS outpatient care in Brazil. Rev Saúde Pública 2006; 40:143-51.

48. Bonolo PF, César CC, Acúrcio FA, Ceccato MGB, Pádua CAM, Álvares J, et al. Non-adherence among patients initiating antiretroviral therapy: a challenge for health professionals in Brazil. AIDS 2005; 19 Suppl 4:S5-13.

49. Habiyambere V, Nguimfack BD, Vojnov L, Ford N, Stover J, Hasek L, et al. Forecasting the global demand for HIV monitoring and diagnostic tests: a 2016-2021 analysis. PLoS One 2018; 13:e0201341. 


\section{Resumo}

A recuperação imunológica reflete condições de saúde. Nosso objetivo foi estimar o tempo até a recuperação imunológica e fatores associados em pessoas vivendo com HIV (PVHIV) após de iniciar a terapia antirretroviral (TARV). Foi conduzida uma coorte histórica de PVHIV (> 18 anos) no Estado de Minas Gerais, Brasil, usando bancos de serviços públicos de saúde. Foram incluídos pacientes que iniciaram a TARV entre 2009 e 2018, com linfócitos $T-C D 4+$ e carga viral registrados antes e depois do início da TARV. O desfecho foi a recuperação imunológica, definida como a primeira contagem de $T-C D 4+>500 \mathrm{cel} / \mu \mathrm{L}$ após o inicio da TARV. As variáveis explanatórias foram idade, sexo, local de residência, ano de início de TARV, carga viral basal, T-CD4+ na linha de base e carga viral e adesão à TARV no seguimento. Foi realizada uma análise descritiva com estimativa de incidência acumulada e taxa de incidência (pessoa-ano). O tempo mediano até a recuperação imunológica foi estimado pelo método Kaplan-Meier. Fatores associados à recuperação imune foram avaliados por meio de regressão de Cox. Entre as 26.430 PVHIV, 8.014 (30\%) foram elegíveis. A maioria era do sexo masculino (67\%), com média de idade $=38,7$ anos, residência em regiões fora da região metropolitana, mediana de T-CD4+ baseline = 228 células $/ \mu L(<200$ células $/ \mu L=43 \%)$ e mediana de carga viral baseline $=4,7 \log _{10}$ cópias $/ \mathrm{mL}$ (carga viral detectável $=99 \%)$. Tempo de seguimento $=15.872$ pessoas-ano. A incidência acumulativa e a taxa de incidência foram foram 58\% (IC95\%: 57-58) ( $n=4.678)$ e 29, 47 casos/100 pessoas-ano, respectivamente. Tempo mediano até recuperação imune $=22,8$ meses (IC95\%: 21,9-24,0). Os fatores independentemente associados com recuperação imunológica foram sexo feminino, idade < 38 anos, T-CD 4+ basal > 200 células $/ \mu L$, carga viral detectável (linha de base), adesão à TARV e carga viral indetectável (no seguimento). O tempo até a recuperação imunológica ainda é longo e impactado pelo tratamento precoce e da adesão à $T A R V$.

Contagem de Linfócito CD4; HIV-1; Terapia Antirretroviral de Alta Atividade

\section{Resumen}

La recuperación inmunológica refleja condiciones de salud. Nuestra meta fue estimar el tiempo y los factores asociados a la recuperación inmunológica en personas que viven con VIH (PVVIH), tras iniciar una terapia antirretroviral (TAR). Se realizó sobre una cohorte histórica entre PVVIH (> 18 años de edad) en Minas Gerais, Brasil, usando datos de las bases de datos del sistema de salud. Se incluyeron a pacientes que comenzaron una TAR entre 2009-2018, con T-CD4+ linfocitos y carga viral, registrada antes/después de TAR. El resultado fue el logro de recuperación inmunológica, definida como la primera T-CD4+ > 500 células/ $\mu$ L tras la iniciación TAR. Las variables explicatorias fueron: edad, género, lugar de residencia, año de iniciación TAR, base de referencia de carga viral, base de referencia de T-CD4+y estatus de la carga viral y adherencia al TAR en el seguimiento. Se estimó: análisis descriptivo, acumulativo e incidencias persona-tiempo de recuperación inmunológica. La media de tiempo para la recuperación inmunológica se estimó usando el método KaplanMeier. Los factores asociados con la recuperación inmunológica se evaluaron mediante la regresión de Cox. Entre las 26.430 PVVIH, 8.014 (30\%) fueron elegibles. La mayoría eran hombres (67\%), media de edad $=38,7$ años, residentes en una región no central, media de base de referencia $T-C D 4+=$ 228 células $/ \mu L(<200$ células $/ \mu L=43 \%)$ y carga viral media de base de referencia $=4,7 \log _{10} \mathrm{co}$ pias $/ m L$ (carga viral detectable $=99 \%$ ). El tiempo de seguimiento $=15.872$ persona-años. La tasa acumulativa y de incidencia fue 58\% (95\%CI: 5758) $(n=4.678)$ y 29,47 casos/100 persona-años, respectivamente. El tiempo de media para la recuperación inmunológica $=22,8$ meses (95\% CI: 21,9-24,0). Género femenino, PVVIH < 38 años de edad, T-CD4+ base de referencia $>200$ células/ $\mu L$, carga viral detectable (base de referencia), adherencia al TAR e carga viral indetectable (seguimiento) estuvieron independientemente asociadas con la recuperación inmunológica. El tiempo para la recuperación inmunológica sigue siendo largo y depende de un tratamiento temprano $y$ de adherencia a la TAR.

Recuento de Linfocito CD4; VIH-1; Terapia Antirretroviral Altamente Activa

Submitted on 06/Jun/2020

Version final resubmitted on 19/Oct/2020 Approved on 17/Dec/2020 